\title{
Labour Economics
}




\section{Other books by J. E. King}

The Political Economy of Marx (with M. C. Howard)

The Economics of Marx (edited, with M. C. Howard)

Relative Income Shares (with P. Regan)

Readings in Labour Economics (editor)

Ten Per Cent and No Surrender: The Preston Strike 1853-4 (with H. I. Dutton)

Economic Exiles

A History of Marxian Economics: Volume 1, 1883-1929 (with M. C. Howard)

Marxian Economics (editor) 


\title{
Labour Economics Second Edition
}

\author{
J. E. King
}


ISBN 978-0-333-48316-9 ISBN 978-1-349-20829-6 (eBook)

DOI 10.1007/978-1-349-20829-6

(C) J. E. King 1972, 1990

Softcover reprint of the hardcover 2nd edition 1990

All rights reserved. For information, write:

Scholarly and Reference Division,

St. Martin's Press, Inc., 175 Fifth Avenue,

New York, N.Y. 10010

This edition first published in the United States of America in 1990

ISBN 978-0-312-04484-8

Library of Congress Cataloging-in-Publication Data

King, J. E. (John Edward)

Labour economics / J. E. King. - 2nd ed.

p. cm.

Includes bibliographical references.

ISBN 978-0-312-04484-8

1. Labour economics. I. Title.

HD4902.K55 1990

$331-\mathrm{dc} 20$

89-77584

CIP 


\section{Contents}

Preface

ix

1 Alternative Approaches to Labour Economics 1

1 Introduction 1

2 Neoclassical economics 2

3 Post-Keynesian theory 3

4 Institutionalism 4

5 Radical-Marxian political economy 6

6 Green economics $\quad 8$

7 Conclusion 10

2 The Demand for Labour 12

1 Neoclassical theory: the short run 12

2 An important qualification $\quad 19$

3 Neoclassical theory: the long run 21

4 Labour as a semi-fixed cost 27

5 Criticisms of neoclassical theory 32

(i) Oligopoly 32

(ii) X-inefficiency 35

(iii) Marginal analysis and empirical research $\quad 37$

6 Non-neoclassical theories of labour demand 40

7 Conclusion $\quad 42$

3 The Supply of Labour 45

1 Introduction 45

2 The short-run neoclassical theory of labour supply $\quad 46$

3 Some extensions 53

(i) Non-wage income 53

(ii) Family influences on individual decisions $\quad 54$ 
(iii) Institutional constraints on working hours 57

(iv) Alternative uses of time 58

4 Neoclassical theory in the long run $\quad 60$

5 Criticisms and alternatives 65

(i) The meaning of work 66

(ii) Problems with human capital theory 69

6 Conclusion $\quad 72$

4 Internal Labour Markets and the Organisation of Work 73

1 The internal labour market 73

2 Neoclassical economics and the internal labour market

3 Institutionalist perspectives $\quad 78$

4 The radical-Marxian approach $\quad 81$

5 Conclusion $\quad 84$

5 Trade Unions $\quad 86$

1 Neoclassical models of union behaviour $\quad 86$

2 Some objections $\quad 92$

3 The bargaining process 96

4 The economic effects of unions 100

5 Conclusion 107

6 Labour Market Discrimination 108

1 The evidence 108

2 Neoclassical models of discrimination 113

3 Institutionalist and radical-Marxian models 122

4 Policies against discrimination 126

7 Wage Differentials 129

1 Introduction 129

2 Pay differences between occupations $\quad 129$

3 Inter-industry differentials 136

4 Geographical differentials $\quad 139$

5 The local labour market 144

6 Dual and segmented labour markets 147 
8 The Distribution of Individual Incomes

1 Evidence on the distribution of incomes 154

2 Inequality and the 'ability to work' 159

3 Alternative approaches 162

4 Poverty and the labour market 165

5 Anti-poverty policy 166

9 Relative Income Shares 172

1 Introduction 172

2 The neoclassical theory of relative income shares 178

3 Post-Keynesian theory 181

4 The radical-Marxian approach 187

5 Theories and evidence 191

10 Unemployment 195

1 The evidence 195

2 Radical-Marxian and green theories of 200

3 Unemployment in neoclassical theory 204

4 Post-Keynesian and institutionalist analysis 212

5 Policies on unemployment 214

11 Wage Inflation and Incomes Policy 218

1 Introduction 218

2 Theories of aggregate wage determination 220

(i) Neoclassical theory 220

(ii) Post-Keynesian, institutionalist and radicalMarxian theories 224

3 Incomes policy 227

12 Conclusion 235

$\begin{array}{ll}\text { Bibliography } & 238\end{array}$

Index 262 


\section{Preface}

This is a completely rewritten and greatly expanded version of a text which was first published in 1972. I am grateful for the helpful comments of Mike Howard, Russell Rimmer, Sheila Rimmer, John Singleton and Jim Taylor, to whom the usual disclaimer applies; and for typing by Maree Hartigan, Monica Hodgkinson, Rosemary Moore and Jenny Sifonios.

J. E. KING 